\title{
The Interdependence of Institutional Framework and Business Success of Internationally Oriented Croatian Road Freight Transporters
}

\author{
Dora NALETINA*, Kristina PETLJAK, Ivana ŠTULEC
}

\begin{abstract}
The road freight industry is a structurally competitive sector which is oriented towards distribution, logistics and basic physical transport. Road freight transport represents the leading transport branch in the European Union, and the same situation is on Croatian transport market. The activities of the Croatian road freight transporters on the foreign market have been continually increasing. This paper aimed to analyse the need for the influence of the institutional framework on the business success of Croatian road freight transporters. Special attention in conducted primary research has been given to examining the relationship between the distribution of the CEMT permits and business success. The results have confirmed that institutional conditions are essential for interpreting the changes in the business success of Croatian road freight transporters. The companies that stated how the CEMT permits and bilateral distribution system negatively influences their business have the lowest average values of the profit (loss) in relation to the assets and the capital. It is crucial to provide more CEMT and bilateral permits for Croatian road freight transporters in the future. It is necessary to coordinate the legislators with the practice to ensure that the amendments that will be adopted in the future also ensure sufficient conditions for successful business.
\end{abstract}

Keywords: bilateral road haulage permit; business success; CEMT permit; Croatian transporters; international road freight transport

\section{INTRODUCTION}

In 2016, transport and storage services (postal and courier activities included) employed around 11.5 million people in the EU-28. Out of the total transport of goods (3.661 billion of tonne-kilometres), $49.3 \%$ was conducted by road [1]. It is important to note that further development of road transport is expected, i.e., it is assumed that the demand for this type of services will increase by $50 \%$ by the year 2050 [2]. Freight transport is essential in today's society, for it facilitates economic and social benefits [3]. The road freight industry is a structurally competitive sector, and the involved parties compete on the price and the service quality. It is oriented towards distribution, logistics and basic physical transport [4]. Since the recession in 2008 has impacted the Croatian economy, Croatian road freight transporters have oriented more outside Croatian borders. In that period demand for services of road freight transporters on Croatian market was much more declining than demand outside of Croatia. That is supported by the fact that the highest decline has been achieved on the short distance (up to $49 \mathrm{~km}$ ) [5]. In the Republic of Croatia, road freight transport also represents the leading transport branch. It should be pointed out that, since 2012 , the activities of the road freight transporters on the foreign market have been continually increasing. This is best supported by the fact that in 2017, Croatian road freight transporters achieved the traffic of 7.634 million of tonne-kilometres on the foreign market, i.e. over $65 \%$ more than in 2008 [6].

In most of the European countries, before their entering into European Union, the regulatory system was developed to satisfy the needs of the nation [7] and Croatia is not an exception. Entrance into European Union, even the pre-accession period, has changed that. The market has been liberalised, and regulation is adjusted according to the legislation of the EU. Ironfield and Moore [8] were examining the regulation of the road freight industry in Australia and OECD countries. They have remarked that most of OECD regulators have moved away from economic regulation, and objective of operator licensing (which covers a range of regulatory approaches) is improvement of safety. While in OECD countries the operator of road transport business has ultimate responsibility, in Australia all involved persons are responsible for their task in the process. Borkowski \& Bąk [9] researched short and long-term consequences of further regulation of the European Union road haulage market. They concluded that current measures, which EU is promoting on road freight market, will have a negative impact on small companies, and especially on those in more peripheral Member countries.

Considering the earlier mentioned and the fact that most of road freight companies on EU market are small ones, this paper aims to investigate the influence of institutional framework on business success of internationally oriented Croatian road freight transporters. It is essential to highlight how special attention is given to the research on the distribution of the insufficient number of the CEMT permits (french. Conférence Européenne des Ministres des Transports; eng. European Conference of Transport Ministers) and bilateral road haulage permit for the business activities of Croatian road freight transporters. It is this insufficient number of the permits that brings into question the successfulness of their operations.

For the purpose of this paper, primary research was conducted. After the introduction, the institutional surroundings of road transporters in the Republic of Croatia were analysed. Further on, the formulation of the hypothesis is explained, and the results of the primary research are presented. Limitations and recommendations for further research are given before the conclusion.

\section{INSTITUTIONAL ENVIRONMENT OF ROAD TRANSPORT IN THE REPUBLIC OF CROATIA}

Often, a market needs to undergo specific changes in the form of market regulation. It is applied if the government deems it necessary to stabilise the particular industry, aiming at the regulation of the prices or the employment [10]. In most of the countries, regulation bodies are spending a high share of their budget on the development of road infrastructure network (either for new roads or for maintenance of old roads) [11]. Regulatory 
policies concerning road transport have many different goals [7]. One of these goals is to ensure that all the transporters have equal status on the market and in this way come closer to an ideal traffic system, which is efficient, reliable and financially stable. Regulatory institutions can under no circumstances give advantage to any participant through special promotions, subventions or tax relieves [12]. To enable domestic road freight transporting firms to be globally competitive, a proper national strategy for road freight is crucial [13]. In each country, the plan of road development impacts the companies' attitude about their investments [14].

The Convention on the Contract for the International Carriage of Goods by Road (CMR Convention) is an instrument of international private law adopted on 19 May 1956. It dictates the contractual relations for the international carriage of goods by road between the sender, the carrier and the consignee. Its provisions are applicable in the cases when the point of loading and the point of delivery of goods are in two different countries. The participants have to satisfy the following cumulative conditions for application of the CMR Convention [15]:

1. At least one of the two countries (country that receives the goods or the country designated for delivery of the goods) must be a signatory party to the CMR Convention. 2. The place of taking over the products and the place designated for delivery must be in two different countries. 3. The carriage of goods must be performed for a person other than the carrier (i.e. carriage for financial reward).

4. At least one portion of the transport must be carried out by a road vehicle.

5. These conditions do not apply to funeral consignments, postal carriage or furniture removals.

Regarding the Croatian legislative, the Civil Obligations Act (cro. Zakon o obveznim odnosima) regulates domestic transporting activities [16]. There are four areas that Croatian road transport law governs: the legal status of the roads as the traffic infrastructure, organisation of the road transport market, traffic safety and the contracts on the road transport of goods [17]. Legal status of the road infrastructure is regulated by the Highway Act (cro. Zakon o cestama) [18], organization and access to the road transport market with the Road Transport Act (cro. Zakon o prijevozu u cestovnom prometu) [19], while road traffic safety is under the regulation of the Road Traffic Safety Act (cro. Zakon o sigurnosti prometa na cestama) [20].

In the European Union, road freight transporters provide international transport which is regulated primarily by the Regulation (EC) No 1072/20092, which lays down the standard rules for access to the occupation of road transport operator and for access to the international road haulage market [21].

Outside the European Union, there are countries Croatia has concluded bilateral agreements with. The most important provision of these agreements relates to the number of international permits both countries can grant their transporters for operating between the two countries.

Unfortunately, regulatory policies have not limited access to the domestic traffic market enough. This has created the situation where there is a surplus of the capacity and the vehicles that are older or lack technical standards. This is the result of the poorly defined criteria for assigning a certain permit quota, which places a substantial burden on Croatian transporters and decreases their competitiveness [22].

In line with the Council Regulation no. 3916/90, in case of a crisis, the state can send a comprehensive report to the Commission which confirms the crisis and the measures for the protection of the domestic transporters are then proposed. These protection measures can be applied for not more than six months, with the possibility of a onetime prolongation, as regulated with the [19]. The state influences the prices of the transport and the competitiveness of its transporters considerably. Through forming the taxes and excise duties, it impacts the fuel prices, which represent $15-30 \%$ of the total costs for road transporters. For the transporters, fuel is the raw material used for the transporting services they provide, and they are not the final consumers. So, it can be said that the price of the fuel for the transporters should be lower than for the final consumers, the fact which could also influence the increase of the competitiveness of our transporters [22]. Croatian road freight market is also burdened with the fact that different counties undergo different policies regarding the fixed costs. The firms pay the insurance policies according to the headquarters of the firm, and they vary from county to county. This discrimination should be eliminated because the transport is performed not just in the county where the firm's headquarters are situated, but they also operate across the counties, and across other countries [23].

Since it was founded in 1953, the European Conference of Ministers of Transport (CEMT) has been trying to facilitate international road transport and integrate the markets in question. CEMT permits are multilateral authorisations for international transport of goods by road performed by a transporting firm from a CEMT Member State, based on the quota system, and the transport is performed among the CEMT Member States, or in transit through one or more CEMT Member states with the vehicles registered in a CEMT Member State [24].

In further years it is expected that in road freight transport automated and autonomous vehicles will be included. Road freight vehicles with small capacity will be mostly used in the urban areas. That as well reflects the need for ensuring adequate institutional framework for further development of road freight transporters [25].

The Regulation should arrange the traffic market better, especially regarding domestic transportation. The sometimes cruel traffic market entices transporting firms to set the fares below the level of profitability, which then results in entering the grey economy and the reduction of labours rights [22]. The government and the industry should work together to create favourable institutional conditions on the road freight market, which would ensure the necessary system reform [26].

\section{RESEARCH METHODOLOGY}

In this chapter, the hypothesis development is explained. To test the hypothesis, primary research was conducted. Due to that, the sample, data collection methods and research results are described below. 


\subsection{Hypothesis Development}

Institutional environment can have a substantial impact on the development of formal structures in an organisation, often more profound than that exerted by the market. The pressures made by institutions influence the growth of homogeneity of the structures in an institutional environment, and ultimately, companies adopt similar behavioural and organisational structures-institutional isomorphism [27, 28]. To ensure a strong market, the government should conceptualise economic regulations that can stimulate business activities [29].

With Croatian accession to the European Union, a legal or a natural person can perform the service of international public road transport of passengers or goods if it possesses the permit issued by the Union which is in line with the EU ordinances: 1071/2009, 1072/2009 and $1073 / 2009$ [30]. The transport between the EU and other countries is still regulated with the issued permits based on bilateral agreements. Here, the influence of the government on the road industry is best reflected, since, with some countries, we have not bilateral agreements signed, and regarding those countries we have agreements negotiated with, there are only limited number of the permits available. In this way, Croatian road industry protects itself from an uncontrolled import of high number of transporters from the non-member states, but, consequently this also negatively influences the companies that would want to enter the market on a larger scale, but they are instead permitted limited enter based on the number of the permits [17]. The government has also influenced the competitiveness of the road transporters through passing the Working Hours, Mandatory Rest Periods for Mobile Workers and Tracking Systems in Road Transport Act [31].

The Environmental Protection and Energy Efficiency Fund encourages the development of "a cleaner" transport through the incentives for buying the vehicles with EURO 6 standard, the installation of a more efficient use of waste heat from the cooling fluid from the motors when the motors are not operating, the purchase of eco tires and similar efforts. With these activities, the Fund also mainly boosts the competitiveness of Croatian road transporters [32].

The importance of the government is also evident in the fact that every member state has the right to inform the Commission in cases when a crisis emerges on the domestic market by delivering a detailed report about the crisis. Pursuing that, the Commission can undertake temporary measures of limiting transporting capacity from the foreign countries whether by limiting the scope of business for the existing transporting companies or by disabling new companies from entering the market [17]. In line with those as mentioned above, a hypothesis was formulated: Institutional conditions influence business success of Croatian road freight transporting companies.

\subsection{Sample Description}

The sample for this research was selected according to the list of Croatian companies for which road freight is listed as their primary business activity in the Croatian Company Directory of the Croatian Chamber of Economy.
To avoid sending the questionnaire to the companies that are no longer operational, the list of companies that submitted their financial reports for the year 2016 was considered. The questionnaire had been sent to 600 emails, and a total of 118 had been returned.

According to the results, $95.30 \%$ of the companies are fully domestically-owned. The analysis showed that 91 companies $(71.12 \%)$ have less than 20 freight vehicles in their fleets, while only seven companies $(5.93 \%)$ own more than 100 freight vehicles. Only two companies (1.7\%) from the sample stated they offered services on the Croatian territory alone, and all other companies provide their services outside the territory of Croatia as well.

\subsection{Data Collection}

With the aim of collecting useful knowledge on business strategies of road freight transporters in Croatia, an explorative research was conducted on the sample of 10 companies, where the research instrument was a structured interview reminder compound of questions gathered during the overview of domestic and international literature, publicly accessible sources: annual reports, data published at the Croatian Bureau of Statistics and the Croatian Company Directory of the Croatian Chamber of Economy. The conducted research aimed to establish the influence of the institutional framework on the business activities of road freight transporters on the international market.

A highly structured questionnaire was used as the instrument for the analysis of the influence of the institutional framework on the business activities of Croatian road freight transporters on the international market. The questionnaire has been sent to the companies from the Croatian Company Directory of the Croatian Chamber of Economy via email, and it has been designed in the Google docs to make it more user-friendly, and consequently, to ensure more responses. The respondents were asked to answer open and closed-ended questions and to check the level of agreement or disagreement with the given statements, where a Likert scale measured the level of agreement with each statement. The levels of agreement ranged from $1-7$, where 1 indicated complete disagreement and 7 complete agreement with the proposed statement. The questionnaire was filled out by 118 companies, and additional 16 companies responded that road freight was no more a part of their business (the response rate was $20.2 \%$ ).

\subsection{Research Results}

The hypothesis whether the Institutional conditions influence the business success of Croatian road freight transporting companies was tested by multiple regression analysis and the Pearson correlation coefficient. First independent variable, institutional conditions (IC) for bilateral and CEMT permits, was calculated as the sum of answers to two statements measured with a Likert scale (Item 1: The distribution system of bilateral permits has a negative impact on companies business success $(\mu=3.17)$, Item 2: The distribution system of CEMT permits has a negative impact on companies business success $(\mu=$ 3.35)). 
Second independent variable, institutional conditions regarding insurance, stimulations, excise duties, the functionality of the legal system, was acquired as the sum of the answers to six statements (Item 3: Discrimination upon insuring freight vehicle: all-risk insurance, compulsory insurance and liability insurance (different premiums depending on where the home office of the company is situated) negatively influences companies business success $(\mu=4.32)$, Item 4: Stimulations within the "cleaner" transport project have motivated our company to modernize vehicle fleet $(\mu=4.36)$, Item 5: Obligatory use of digital recording equipment (tachographs) positively influences companies business success $(\mu=4.70)$, Item 6: Excise duties system has a negative impact on companies business success $(\mu=5.10)$, Item 7: Inability to perform cabotage services negatively influences companies business success $(\mu=4.55)$ and Item 8: The current legal system in the Republic of Croatia negatively influences companies business success $(\mu=5.19))$.

The dependent variable was examined through the non-market success indicators: profit or loss in relation to the assets (ROA) and profit or loss in relation to the capital (ROE).

Before the multiple regression analysis model the correlation matrix of every independent and the dependent variable was presented, followed by the correlation matrix of independent variables and the dependent variable. Tab. 1 shows how ROE most correlates with the variable measured with the statement "the distribution system of bilateral permits has a negative impact on companies business success" (-0.325; 0.002) while ROA establishes the strongest correlation with the variable examined through the statement" the distribution system of CEMT permits has a negative impact on companies business success" (-0.318; 0.002).

Table 1 Correlation matrix of institutional conditions for bilateral and CEMT permits and the indicators of business success

\begin{tabular}{|c|c|c|c|c|c|c|}
\hline & & 1 & 2 & 3 & 4 & 5 \\
\hline \multirow{3}{*}{$\begin{array}{l}\text { Item 1: The distribution system of bilateral permits has a negative impact on companies } \\
\text { business success. }\end{array}$} & $P$ & & & & & \\
\hline & $S$ & & & & & \\
\hline & $N$ & & & & & \\
\hline \multirow{3}{*}{$\begin{array}{l}\text { Item 2: The distribution system of CEMT permits has a negative impact on companies } \\
\text { business success. }\end{array}$} & $P$ & $0.871^{* *}$ & & & & \\
\hline & $S$ & 0.000 & & & & \\
\hline & $N$ & 110 & & & & \\
\hline \multirow{3}{*}{ Institutional conditions for bilateral and CEMT permits. } & $P$ & $0.965 * *$ & $0.969 * *$ & & & \\
\hline & $S$ & 0.000 & 0.000 & & & \\
\hline & $N$ & 110 & 110 & & & \\
\hline \multirow{3}{*}{ ROE } & $P$ & $-0.325 * *$ & $-0.318^{* *}$ & $-0.334 * *$ & & \\
\hline & $S$ & .002 & 0.002 & 0.001 & & \\
\hline & $N$ & 92 & 92 & 92 & & \\
\hline \multirow{3}{*}{ ROA } & $P$ & $-0.284 * *$ & $-0.318^{* *}$ & $-0.309 * *$ & $0.583 * *$ & \\
\hline & $S$ & 0.005 & 0.002 & 0.002 & 0.000 & \\
\hline & $N$ & 95 & 95 & 95 & 92 & \\
\hline
\end{tabular}

Table 2 Correlation matrix of institutional conditions: insurance conditions, stimulations, excise duties and legal system functionality and the indicators of business success

\begin{tabular}{|c|c|c|c|c|c|c|c|c|c|c|}
\hline & & 1 & 2 & 3 & 4 & 5 & 6 & 7 & 8 & 9 \\
\hline \multirow{3}{*}{$\begin{array}{l}\text { Item 3: Discrimination upon insuring freight vehicle: all-risk } \\
\text { insurance, compulsory insurance and liability insurance (different } \\
\text { premiums depending on where the home office of the company is } \\
\text { situated) negatively influences companies business success. }\end{array}$} & $P$ & & & & & & & & & \\
\hline & $S$ & & & & & & & & & \\
\hline & $N$ & & & & & & & & & \\
\hline \multirow{3}{*}{$\begin{array}{l}\text { Item 4: Stimulations within the "cleaner" transport project have } \\
\text { motivated our company to modernize vehicle fleet. }\end{array}$} & $P$ & 0.095 & & & & & & & & \\
\hline & $S$ & 0.316 & & & & & & & & \\
\hline & $N$ & 113 & & & & & & & & \\
\hline \multirow{3}{*}{$\begin{array}{l}\text { Item 5: Obligatory use of digital recording equipment } \\
\text { (tachographs) positively influences companies business success. }\end{array}$} & $P$ & -0.009 & $0.393 * *$ & & & & & & & \\
\hline & $S$ & 0.925 & 0.000 & & & & & & & \\
\hline & $N$ & 113 & 113 & & & & & & & \\
\hline \multirow{3}{*}{$\begin{array}{l}\text { Item 6: Excise duties system has a negative impact on companies } \\
\text { business success. }\end{array}$} & $P$ & $0.415 * *$ & -0.123 & 0.015 & & & & & & \\
\hline & $S$ & 0.000 & 0.194 & 0.877 & & & & & & \\
\hline & $N$ & 113 & 113 & 113 & & & & & & \\
\hline \multirow{3}{*}{$\begin{array}{l}\text { Item 7: Inability to perform cabotage services negatively } \\
\text { influences companies business success. }\end{array}$} & $P$ & 0.038 & 0.020 & 0.017 & $0.195^{*}$ & & & & & \\
\hline & $S$ & 0.689 & 0.832 & 0.854 & 0.039 & & & & & \\
\hline & $N$ & 113 & 113 & 113 & 113 & & & & & \\
\hline \multirow{3}{*}{$\begin{array}{l}\text { Item 8: The current legal system in the Republic of Croatia } \\
\text { negatively influences companies business success. }\end{array}$} & $P$ & $0.236^{*}$ & -0.029 & 0.126 & $0.324 * *$ & $0.188^{*}$ & & & & \\
\hline & $S$ & 0.012 & 0.757 & 0.184 & 0.000 & 0.047 & & & & \\
\hline & $N$ & 113 & 113 & 113 & 113 & 113 & & & & \\
\hline \multirow{3}{*}{$\begin{array}{l}\text { Institutional conditions: insurance conditions, stimulations, excise } \\
\text { duties and legal system functioning }\end{array}$} & $P$ & $0.407 * *$ & $-0.458 * *$ & $-0.387 * *$ & $0.491 * *$ & $0.488^{* *}$ & $0.446^{* *}$ & & & \\
\hline & $S$ & 0.000 & 0.000 & 0.000 & 0.000 & 0.000 & \begin{tabular}{|l|}
0.000 \\
\end{tabular} & & & \\
\hline & $N$ & 109 & 109 & 109 & 109 & 109 & 109 & & & \\
\hline \multirow{3}{*}{ ROE } & $P$ & -0.148 & -0.038 & -0.040 & 0.013 & -0.193 & -0.118 & $-0.301 * *$ & & \\
\hline & $S$ & 0.154 & 0.714 & 0.703 & 0.900 & 0.062 & 0.259 & 0.004 & & \\
\hline & $N$ & 94 & 94 & 94 & 94 & 94 & 94 & 92 & & \\
\hline \multirow{3}{*}{ ROA } & $P$ & 0.005 & 0.087 & 0.087 & 0.042 & $-0.268 * *$ & -0.112 & $-0.444 * *$ & $0.583^{* *}$ & \\
\hline & $S$ & 0.963 & 0.393 & 0.394 & \begin{tabular}{|l|}
0.683 \\
\end{tabular} & 0.008 & \begin{tabular}{|l|}
0.273 \\
\end{tabular} & 0.000 & 0.000 & \\
\hline & $N$ & 98 & 98 & 98 & 98 & 98 & 98 & 98 & 92 & \\
\hline
\end{tabular}


In the correlation matrix of the second independent variable and the indicators of business successfulness (Tab. 2 ), it can be noticed that both ROE and ROA have the highest level of correlation with the inability to perform cabotage transport services.

If we are to observe the independent variable of institutional conditions: insurance conditions, stimulations, excise duties and legal system functionality, we conclude that it has the highest correlation with the excise duties system $(0.491 ; 0.000)$.

Tab. 3 shows that both ROA and ROE negatively correlate with both independent variables, and while ROE correlates more strongly with the institutional conditions for bilateral and CEMT permit $(-0.334 ;-0.001)$, ROA correlates with institutional conditions related to insurance conditions, stimulations, excise duties and legal system functioning $(-0.444 ; 0.000)$.

Table 3 Correlation matrix of institutional conditions and the indicators of business success

\begin{tabular}{|c|c|c|c|c|c|}
\hline \multicolumn{6}{|c|}{ business success } \\
\hline & & 1 & 2 & 3 & 4 \\
\hline \multirow{3}{*}{$\begin{array}{l}\text { Institutional conditions of } \\
\text { bilateral and CEMT } \\
\text { conditions (IC1) }\end{array}$} & $P$ & & & & \\
\hline & $S$ & & & & \\
\hline & $N$ & & & & \\
\hline \multirow{3}{*}{$\begin{array}{l}\text { Institutional conditions: } \\
\text { insurance conditions, } \\
\text { stimulations, excise duties } \\
\text { and legal system } \\
\text { functioning (IC2) }\end{array}$} & $P$ & $0.238 *$ & & & \\
\hline & $S$ & 0.013 & & & \\
\hline & $N$ & 108 & & & \\
\hline \multirow{3}{*}{ ROE } & $P$ & $-0.334 * *$ & $-0.299 * *$ & & \\
\hline & $S$ & 0.001 & 0.004 & & \\
\hline & $N$ & 92 & 93 & & \\
\hline \multirow{3}{*}{ ROA } & $P$ & $-0.309 * *$ & $-0.444 * *$ & $0.583 * *$ & \\
\hline & $S$ & 0.002 & 0.000 & 0.000 & \\
\hline & $N$ & 95 & 98 & 92 & \\
\hline \multicolumn{6}{|c|}{ * Significance correlation $p<0.05$} \\
\hline \multicolumn{6}{|c|}{$\begin{array}{l}\text { ** Significance correlation } p<0.01 \\
P \text {-Pearson correlation coefficient; } S \text {-significance; } N \text {-sample size }\end{array}$} \\
\hline
\end{tabular}

The following section presents the results of the multiple regression model used for examining the influence of institutional conditions for bilateral and CEMT permits (IC1) and institutional conditions for insurance, stimulations, excise duties and legal system arrangement (IC2) on business success. HAC correction has been used for correcting the problem of heteroscedasticity.

Considering the results of the regression analysis presented in Tab. 4, it can be acknowledged that institutional conditions influence the profit (loss) regarding the asset. Since the dependent variable is seen through ROE as well, the results of that regression model are given below.

Table 4 The first regression model of the hypothesis (influence of institutiona conditions on profit (loss) regarding the asset)

\begin{tabular}{|c|c|c|c|c|}
\hline \multicolumn{5}{|c|}{ Dependent Variable: ROA } \\
\hline \multicolumn{5}{|c|}{ Method: Least Squares } \\
\hline \multicolumn{5}{|c|}{ Sample (adjusted): 2118} \\
\hline \multicolumn{5}{|c|}{ Included observations: 95 after adjustments } \\
\hline \multicolumn{5}{|c|}{$\begin{array}{l}\text { HAC standard errors \& covariance (Bartlett kernel, Newey-West fixed } \\
\text { bandwidth }=4.0000)\end{array}$} \\
\hline Variable & Coefficient & $\begin{array}{l}\text { Std. } \\
\text { Error }\end{array}$ & t-Statistic & Prob. \\
\hline $\mathrm{C}$ & 33.49278 & 7.858922 & 4.261752 & 0.0000 \\
\hline IU1 & -0.782326 & 0.235372 & -3.323780 & 0.0013 \\
\hline IU2 & -0.714749 & 0.242714 & -2.944817 & 0.0041 \\
\hline$R$-squared & 0.230168 & \multicolumn{2}{|c|}{ Mean dependent var } & 9.304381 \\
\hline $\begin{array}{l}\text { Adjusted } R- \\
\text { squared }\end{array}$ & 0.213433 & \multicolumn{2}{|c|}{ S.D. dependent var } & 12.86570 \\
\hline S.E. of regression & 11.41041 & \multicolumn{2}{|c|}{ Akaike info criterion } & 7.737999 \\
\hline Sum squared resid & 11978.16 & \multicolumn{2}{|c|}{ Schwarz criterion } & 7.818647 \\
\hline Log likelihood & -364.5549 & \multicolumn{2}{|c|}{ Hannan-Quinn criter. } & 7.770587 \\
\hline$F$-statistic & 13.75333 & \multicolumn{2}{|c|}{ Durbin-Watson stat } & 2.007735 \\
\hline Prob ( $F$-statistic) & 0.000006 & & & \\
\hline
\end{tabular}

Fig. 1 represents the average grade of items which measured institutional conditions in Croatian road freight industry. It can be seen that the highest average grade $(\mu=$ 5.19) is for the item: The current legal system in the Republic of Croatia negatively influences companies business.

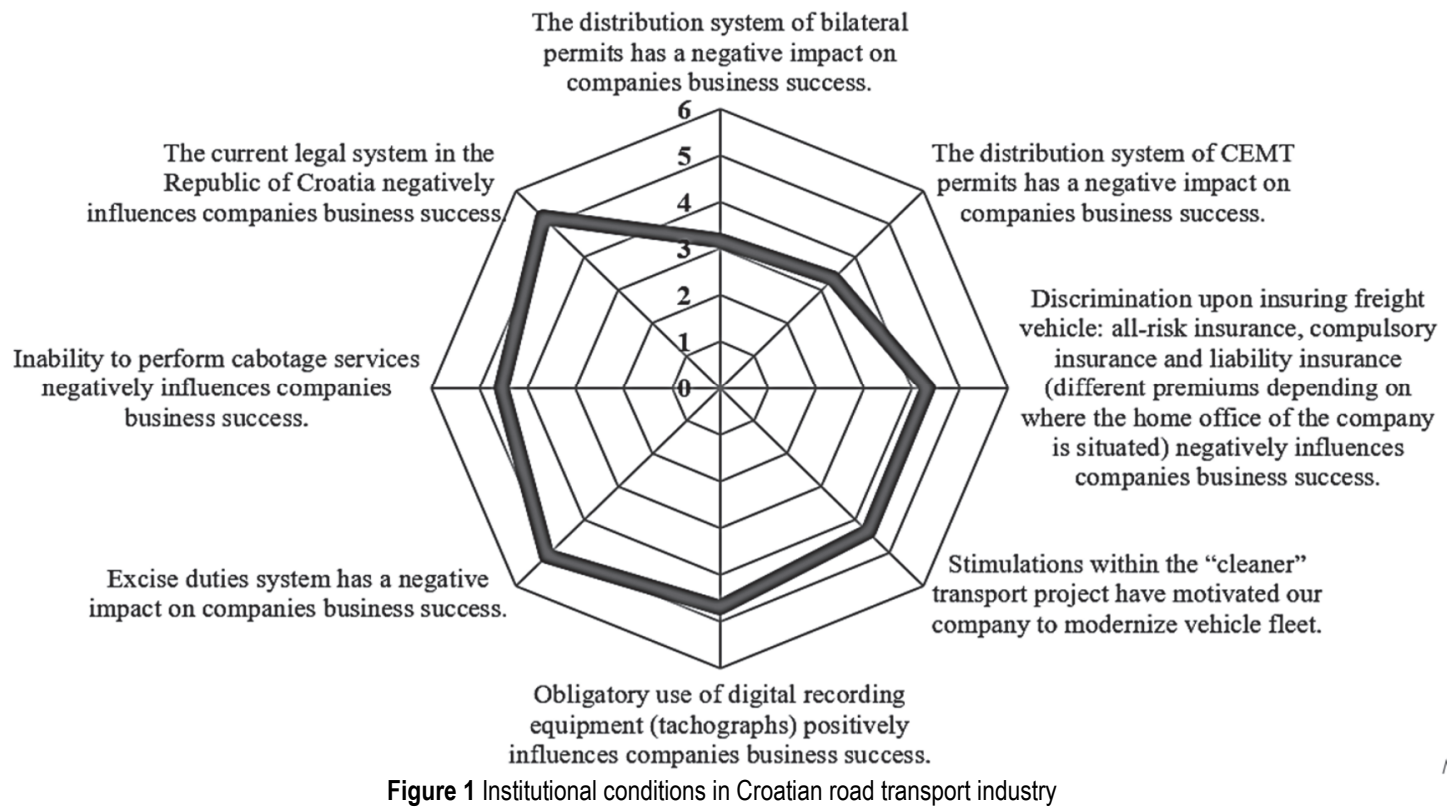

Coefficient of determination in this model is $15.69 \%$. In Tab. 5 , coefficients of the independent variables have a negative sign, i.e. institutional conditions have a negative influence on the business success of the companies in the Croatian road transport industry. 
Table 5 The second regression model of the second hypothesis (the influence of institutional conditions on the profit (loss) regarding the capital)

\section{Dependent Variable: ROE}

Method: Least Squares

Sample (adjusted): 2118

Included observations: 91 after adjustments

HAC standard errors \& covariance (Bartlett kernel, Newey-West fixed bandwidth $=4.0000$ )

\begin{tabular}{|l|c|c|c|c|}
\hline \multicolumn{1}{|c|}{ Variable } & Coefficient & Std. Error & $t$-Statistic & Prob. \\
\hline \multicolumn{1}{|c|}{ IU1 } & 56.32566 & 11.03391 & 5.104779 & 0.0000 \\
\hline \multicolumn{1}{|c|}{ IU2 } & -1.539409 & 0.481200 & -3.199102 & 0.0019 \\
\hline$R$-squared & 0.156899 & Mean dependent var & 24.65418 \\
\hline $\begin{array}{l}\text { Adjusted } R \text { - } \\
\text { squared }\end{array}$ & 0.137738 & S.D. dependent var & 23.14891 \\
\hline $\begin{array}{l}\text { S.E. of } \\
\text { regression }\end{array}$ & 21.49564 & Akaike info criterion & 9.005989 \\
\hline $\begin{array}{l}\text { Sum squared } \\
\text { resid }\end{array}$ & 40661.50 & \multicolumn{2}{|c|}{ Schwarz criterion } & 9.088764 \\
\hline Log likelihood & -406.7725 & Hannan-Quinn criter. & 9.039383 \\
\hline$F$-statistic & 8.188289 & \multicolumn{2}{|c|}{ Durbin-Watson stat } & 2.376074 \\
\hline Prob $(F$-statistic $)$ & 0.000548 & \multicolumn{4}{l}{} \\
\hline
\end{tabular}

The relationship between the regulation of insurance, stimulations, excise duties and legal system functioning and ROE can be seen in Fig. 2. It can be concluded that both independent variables negatively influence business successfulness of companies in Croatian road freight industry.

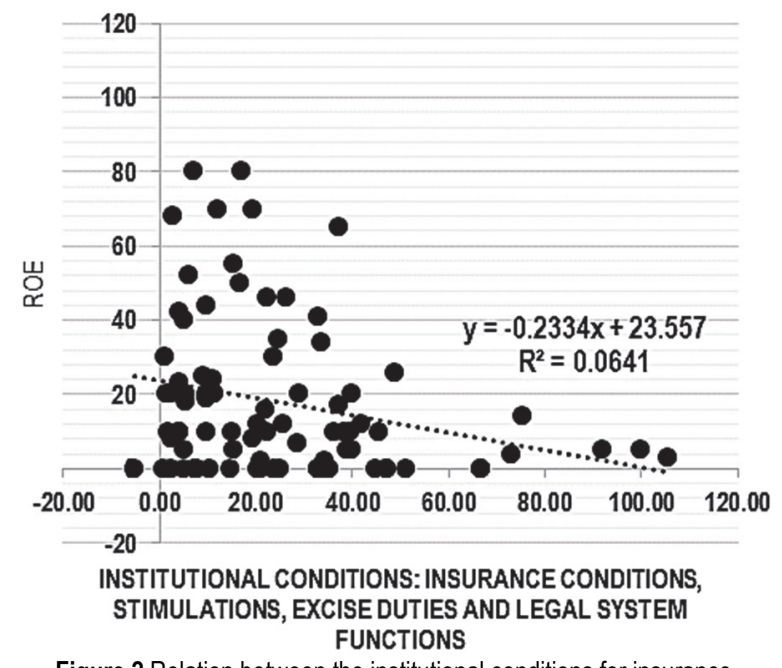

Figure 2 Relation between the institutional conditions for insurance stimulations, excise duties and legal system organisation and the profit (loss) regarding the capital

Based on the data of the conducted regression analyses, as well as due to the significant correlation between institutional conditions and business success, the hypothesis is confirmed, i.e. institutional conditions influence business successfulness of the companies in Croatian road freight industry.

Tab. 6 shows that the system of distribution of bilateral permits significantly influences the profit (loss) in relation to the capital and the asset. Companies that have stated that the system for bilateral permit distribution has negative influence on their business have the lowest average values for both indicators of business success, while companies that think the system of bilateral permit distribution does not negatively influence their business activities, have the highest average profit (loss) regarding the asset and the capital.
Table 6 Variance analysis of the system of distribution of bilateral permits and the indicators of business success

\begin{tabular}{|c|c|c|c|c|c|c|}
\hline & & $N$ & Mean & $S D$ & $\begin{array}{c}\text { Homogeneity } \\
\text { Sig. }\end{array}$ & Sig. \\
\hline \multirow{4}{*}{$\begin{array}{l}\text { share of profit } \\
\text { in the } \\
\text { capital/system } \\
\text { of distribution } \\
\text { of bilateral } \\
\text { permits }\end{array}$} & Disagree & 58 & 30.88 & 25.82 & \multirow{4}{*}{0.002} & \multirow{4}{*}{0.003} \\
\hline & $\begin{array}{c}\text { Neither } \\
\text { agree } \\
\text { nor } \\
\text { disagree }\end{array}$ & 13 & 16.66 & 12.53 & & \\
\hline & Agree & 22 & 13.38 & 11.26 & & \\
\hline & Total & 93 & 24.75 & 22.94 & & \\
\hline \multirow{4}{*}{$\begin{array}{l}\text { share of the } \\
\text { profit in the } \\
\text { asset/system } \\
\text { of distribution } \\
\text { of bilateral } \\
\text { permits }\end{array}$} & Disagree & 60 & 11.93 & 14.75 & \multirow{4}{*}{0.007} & \multirow{4}{*}{0.034} \\
\hline & $\begin{array}{l}\text { Neither } \\
\text { agree } \\
\text { nor } \\
\text { disagree }\end{array}$ & 11 & 6.96 & 11.02 & & \\
\hline & Agree & 25 & 4.30 & 4.35 & & \\
\hline & Total & 96 & 9.37 & 12.81 & & \\
\hline
\end{tabular}

Tab. 7 shows that the system of distribution of CEMT permits significantly influences the profit (loss) in relation to the capital and the asset. Companies that think the system for CEMT permit distribution has a negative influence on their business have the lowest average values for both indicators of business success, while companies that think the system of CEMT permit distribution does not negatively influence their business activities, have the highest average profit (loss) regarding the asset and the capital.

Table 7 Variance analysis of the distribution system of CEMT permits and the

\begin{tabular}{|c|c|c|c|c|c|c|}
\hline & & $\begin{array}{l}\text { Sample } \\
\text { size }\end{array}$ & Mean & $\begin{array}{l}\text { Standard } \\
\text { deviation }\end{array}$ & $\begin{array}{c}\text { Homogeneity } \\
\text { Sig. }\end{array}$ & Sig. \\
\hline \multirow{4}{*}{$\begin{array}{l}\text { share of } \\
\text { profit in } \\
\text { the capital } \\
\text { / system of } \\
\text { distribution } \\
\text { of CEMT } \\
\text { permits }\end{array}$} & Disagree & 54 & 30.36 & 25.75 & \multirow{4}{*}{0.044} & \multirow{4}{*}{0.017} \\
\hline & $\begin{array}{c}\text { Neither } \\
\text { agree } \\
\text { nor } \\
\text { disagree }\end{array}$ & 12 & 20.12 & 19.11 & & \\
\hline & Agree & 27 & 15.60 & 13.95 & & \\
\hline & Total & 93 & 24.75 & 22.94 & & \\
\hline \multirow{4}{*}{$\begin{array}{l}\text { share of } \\
\text { the profit } \\
\text { in the asset } \\
\text { / system of } \\
\text { distribution } \\
\text { of CEMT } \\
\text { permits }\end{array}$} & Disagree & 56 & 12.72 & 15.07 & \multirow{4}{*}{0.002} & \multirow{4}{*}{0.009} \\
\hline & $\begin{array}{l}\text { Neither } \\
\text { agree } \\
\text { nor } \\
\text { disagree }\end{array}$ & 11 & 5.65 & 10.46 & & \\
\hline & Agree & 29 & 4.32 & 4.21 & & \\
\hline & Total & 96 & 9.37 & 12.81 & & \\
\hline
\end{tabular}

\subsection{Limitations and Recommendations for Future Research}

To test the hypothesis, the data were collected concerning business success which was observed through the values of the profit (loss) in relation to the assets and the profit (loss) in relation to the capital only for the year 2016. This is precisely one of the limitations of the research. Therefore, the recommendation is that future researches use the average values of the presented indicators from the last five years at least. On the other hand, business success can be tested with the statements from earlier researches which have observed the same variable. 


\section{CONCLUSION}

Road freight industry has for years presented an essential mode of transport, and the indicators show that its significance will only rise in the future. Since Croatian road transport companies are orienting more and more towards the international market, the purpose of this paper was to establish how the institutional framework influences their business success. Special attention has been given to examining the relation between the distribution of CEMT permits and business success.

The results of the research have confirmed that institutional conditions are essential for interpreting the changes in the business success of Croatian road freight transporters. The results of the regression and the correlation coefficient lead to the conclusion that institutional conditions negatively influence the business success of Croatian road transport companies. The companies that stated how the CEMT permits distribution system negatively impacts their business have the lowest average values of the profit (loss) in relation to the assets and the capital. The same results have been confirmed in an analysis of the impact of bilateral permit distribution system. It is crucial to provide more CEMT and bilateral permits for Croatian road transporters in the future, not just to ensure their better positioning on the foreign market, but also to create preconditions for achieving better business results.

Most respondents stated that the current legal system in the Republic of Croatia has a negative impact on their business activities, which implies that it is necessary to coordinate the legislators with the practice to ensure the amendments that will be adopted in the future also ensure sufficient conditions for successful business. To tackle the problem of discrimination regarding the insurance, i.e. paying different premiums regarding the headquarters of the company, it is paramount to adopt the amendments of the Law in the near future. On the other hand, one cannot neglect the negative influence of high fees for positioning Croatian road transporters on the international market. The Republic of Croatia is one of the EU member states with the highest fees, and the respondents have confirmed that the high costs of the fees negatively influence their business success. All the market agents should be provided with the same business conditions.

\section{REFERENCES}

[1] European Commission. Statistical pocketbook 2018. EU TRANSPORT in figures. Luxembourg: Publications Office of the European Union, 2018.

[2] Raczkowski, K., Schneider, F., \& Laroche, F. (2017). The Impact of Regulation of the Road Transport Sector on Entrepreneurship and Economic Growth in the European Union. Retrieved from https://www.mobilelabour.eu/wpcontent/uploads/2018/02/The-Impact-of-Regulation-of-theRoad-Transport-Sector-on-Entreperneurship-andEconomic-Growth.pdf

[3] Arvidsson, N., Woxenius, J., \& Lammgård, C. (2013) Review of road hauliers' measures for increasing transport efficiency and sustainability in urban freight distribution. Transport Reviews, 33(1), 107-127. http://dx.doi.org/10.1080/01441647.2013.763866

[4] Boylaud, O. \& Nicoletti, G. (2001). Regulatory reform in road freight. OECD Economic studies, 2001(1), 229-251. https://doi.org/10.1787/eco studies-v2001-art7-en

[5] Rajsman, M., Luburić, G., \& Muhin, M. (2017). Dynamics and trends of the development of transport relations in road freight transport. Tehnički vjesnik: znanstveno-stručni časopis tehničkih fakulteta Sveučilišta u Osijeku, 24(2), 635642. https://doi.org/10.17559/TV-20151222091742

[6] Croatian Bureau of Statistics. Statistical Yearbook 2018 of the Republic of Croatia. Zagreb: Croatian Bureau of Statistics; December 2018.

[7] Bayliss, B. (1998). Regulation in the road freight transport sector. Journal of Transport Economics and Policy, 32(1), 113-131

[8] Ironfield, D., \& Moore, B. (2002, October). Regulation of the road freight industry-evidence on the effectiveness of operator licensing. In $25^{\text {th }}$ Australiasian Transport Research Forum Incorporating the BTRE Trasnport Policy Colloquium, Canberra. Retrieved from https://pdfs.semanticscholar.org/f861/8df5da6f44e57a76d0 8162d7023374d03902.pdf

[9] Borkowski, P. \& Bąk, M. (2018). Short and long-term consequences of further regulation of the European Union road haulage market. Journal of Management and Financial Sciences, 9(33), 9-23.

[10] Hoj, J., Kato, T., \& Pilat, D. (1995). Deregulation and privatisation in the service sector. OECD Economic Studies, (25), 37-74.

[11] Šuman, N., Dolaček-Alduk, Z., \& Klanšek, U. (2018). Construction Procedures for Public Goods on Roads of Local Interest in Slovenia. Tehnički vjesnik, 25(Supplement 1), 231-239. https://doi.org/10.17559/TV-20170721124145

[12] Londoño-Kent P. Freight transport for development toolkit: Road Freight 2009. Retrieved from:

http://www.ppiaf.org/freighttoolkit/sites/default/files/pdfs/r oad.pdf

[13] Sulaiman, M. Y. (1997). Developing a national strategy for the road haulage industry in Malaysia. In Proceedings of the Eastern Asia Society for Transportation Studies, 1, 207-221.

[14] Mrowczynska, B., Ciesla, M., Krol, A., \& Sladkowski, A. (2017). Application of Artificial Intelligence in Prediction of Road Freight Transportation. Promet-Traffic \& Transportation, 29(4), 363-370. https://doi.org/10.7307/ptt.v29i4.2227

[15] International Road Union. CMR-Frequently Asked Questions. Geneva: International Road Union; March 2017.

[16] Radionov, N. (2009). Odgovornost cestovnog prijevoznika za robu i poslovi osiguranja. Osiguranje, 12(1).

[17] Radionov, R., N. (2006). Tržište usluga prijevoza robe cestom u Hrvatskoj: vode li ceste u EU?. Zbornik Pravnog fakulteta u Zagrebu, 56(Special Issue), 567-590.

[18] Official Gazette. [the Highway Act]. Zagreb: Narodne novine d. d., 2014, No. 92

[19] Official Gazette. Zakon o prijevozu u cestovnom prometu. Zagreb: Narodne novine d. d., 2013, No.82.

[20] Official Gazette. Zakon o sigurnosti prometa na cestama. Zagreb: Narodne novine d. d., 2015; No. 64

[21] European Commission Regulation of the European Parliament and of the Council on common rules ensuring basic road freight connectivity with regard to the withdrawal of the United Kingdom of Great Britain and Northern Ireland from the Union. Brussels: European Commission; 19 December 2018.

[22] Banelli, M., Kolak, A., \& Vukadinović, D. (2009). Priručnik za međunarodni cestovni promet. Zagreb: Banelli d.o.o.

[23] Faculty of Transport and Traffic Sciences Zagreb (2006). Analiza tržišta cestovnog prijevoza u Republici Hrvatskoj. Retrieved from: http://www.mppi.hr/userdocsimages/2008/ATCPRH_studij a_FPZ.pdf.

[24] Ministry of the Sea, Transport and Infrastructure. CEMT (ECMT) multilateralne dozvole. 2008. Retrieved 
fromhttp://www.mppi.hr/userdocsimages/2008/060906CEMT-info.pdf.

[25] Csiszár, C. \& Földes, D. (2018). System model for autonomous road freight transportation. Promet-Traffic \& Transportation, 30(1), 93-103.

https://doi.org/10.7307/ptt.v30i1.2566

[26] Newnam, S., Goode, N., Salmon, P., \& Stevenson, M. (2017). Reforming the road freight transportation system using systems thinking: An investigation of Coronial inquests in Australia. Accident Analysis \& Prevention, 101, 28-36. https://doi.org/10.1016/j.jaap.2017.01.016

[27] Meyer, J. W. \& Rowan, B. (1977). Institutionalized organizations: Formal structure as myth and ceremony. American journal of sociology, 83(2), 340-363. https://doi.org/10.1086/226550

[28] DiMaggio, P. J. \& Powell, W. W. (1991). The new institutionalism in organizational analysis. Chicago: University of Chicago Press.

https://doi.org/10.7208/chicago/9780226185941.001.0001

[29] Cui, H. J., \& MA, T. S. (2009). Economic mechanism of government regulation for road freight transportation. Journal of Chang'an University (Social Science Edition), 1. Retrieved from: http://en.cnki.com.cn/Article_en/ CJFDTOTAL-XBJZ200901008.htm

[30] Ministry of the Sea, Transport and Infrastructure. Za međunarodni cestovni prijevoz tereta ili putnika od 1.srpnja 2013. potrebna licencija Zajednice. 2013. Retrieved from $\mathrm{http}: / / \mathrm{mppi} . \mathrm{hr} /$ default.aspx?id=9881.

[31] Official Gazette. [Working Hours, Mandatory Rest Periods for Mobile Workers and Tracking Systems in Road Transport Act]. Zagreb: Narodne novine d. d., 2013, No.75.

[32] Ministarstvo mora, prometa $i$ infrastrukture \& Fond za zaštitu okoliša i energetsku učinkovitost. Natječaj za javno prikupljanje ponuda za neposredno sudjelovanje Fonda za zaštitu okoliša i energetsku učinkovitost i Ministarstva mora, prometa i infrastrukture u financiranju zamjene cestovnih vozila prema programu smanjenja negativnog utjecaja prometa na okoliš - prva mjera: smanjenje emisije štetnih plinova cestovnih vozila (kategorije N2, N3, M3) za 2009. godinu, 2009. Retrieved from: http://www.mppi.hr/ UserDocsImages/EURO\%205\%20-\%20NATJECAJ_37.pdf

\section{Contact information:}

Dora NALETINA, Assistant Professor

(Corresponding author)

University of Zagreb, Faculty of Economics \& Business,

Department of Trade and International Business,

J. F. K. Square 6, 10000 Zagreb, Croatia

E-mail: dora.naletina@efzg.hr

Kristina PETLJAK, Assistant Professor

University of Zagreb, Faculty of Economics \& Business,

Department of Trade and International Business,

J. F. K. Square 6, 10000 Zagreb, Croatia

E-mail: kpetljak@efzg.hr

Ivana ŠTULEC, Assistant Professor

University of Zagreb, Faculty of Economics \& Business,

Department of Trade and International Business,

J. F. K. Square 6, 10000 Zagreb, Croatia

E-mail: istulec@efzg.hr 